\title{
Metal Accumulation and Metallothionein Response in Fucus spiralis
}

\author{
J. F. P. Oaten ${ }^{1}$, M. C. Gibson ${ }^{2}$, M. D. Hudson ${ }^{3}$, A. C. Jensen ${ }^{4}$, I. D. Williams ${ }^{5}$ \\ ${ }^{1,2,3,5}$ Centre for Environmental Science, Faculty of Engineering and the Environment, University of Southampton, \\ University Road, Highfield, Southampton, Hampshire, SO17 1BJ, United Kingdom \\ jfpo1g13@soton.ac.uk; mdh@soton.ac.uk; idw@soton.ac.uk \\ ${ }^{4}$ Ocean and Earth Science, University of Southampton, Waterfront Campus, National Oceanography Centre, European \\ Way, Southampton, Hampshire, SO14 3ZH, United Kingdom \\ ajc@noc.soton.ac.uk
}

\begin{abstract}
Seaweeds are established sentinels for metal contamination and are utilised for biomonitoring. Metallothionein (MT) is a protein that is induced by metal exposure, and has been widely used as a biomarker for metal pollution. MT has not been reported in spiral wrack (Fucus spiralis), but has been identified in bladder wrack (Fucus vesiculosus), where it has been suggested as a protective mechanism against metal exposure. This study aimed to evaluate the potential use of MT in $F$. spiralis as a biomarker for metal pollution for the first time. Samples were collected from Poole Harbour, UK, over a year-long period, from January to October 2015. MT and metal concentrations were quantified during winter, spring, summer, and autumn seasons. Linear regression analysis showed few relationships between MT and metal concentrations, apart from in summer. During summer, significant positive relationships existed between MT concentrations and iron $\left(R^{2}=0.631\right)$, nickel $\left(R^{2}=0.486\right)$, tin $\left(R^{2}=0.579\right)$, and lead $\left(R^{2}=0.415\right)$. It is possible that for most of the year, metal concentrations in Poole Harbour are not high enough to elicit a MT response in $F$. spiralis, as it is a metal tolerant species. However, during summer, rates of photosynthesis and growth increase, which may increase metal toxicity, due to the inhibition of photosynthesis and growth. Thus, MT may be induced in order to prevent disruption. This study suggests that the use of MT as a biomarker for metal pollution in $F$. spiralis may not be a sensitive biomarker at low levels of metal pollution. However, MT concentrations in F. spiralis may respond to metal exposure when natural processes are vulnerable to pollution. The potential for MT to be used as a biomarker in Fucus spp. has been highlighted, warranting further research to develop a promising cosmopolitan bioindicator for metal pollution.
\end{abstract}

Keywords: Metallothionein induction - metal toxicity - biomonitoring - brown seaweed

\section{Introduction}

Seaweeds are advocated as bioindicators in temperate coastal waters due mainly to their high abundances and immobility [1]. They often dominate metal contaminated habitats [2] and are resistant to metal pollution [3]. They have an ability to accumulate dissolved metals from seawater so their intracellular concentrations reflect time-integrated pollution loads in the marine environment [4]. As a consequence, seaweeds are established sentinels for metal contamination and are exploited for biomonitoring [5].

Metallothionein (MT) is a protein of low molecular weight, high heat stability, and high cysteine content [6]. The latter attribute lends itself to be used as a biomarker of metal pollution, as it has a high affinity to bond to metals due to sulphur-containing thiol groups [7]. It is regarded to play a vital role in the detoxification of metals within organisms [7, 8]. This relays a biological response indicating the severity of metal pollution to the organism. Many organisms have been employed as a MT biomarker species, primarily bivalve species [9-13]. However, MT is also noted to have multiple roles such as maintaining homeostasis by regulating essential metals, and as a defence against reactive oxygen species [14, 15]. Factors that contribute to natural variation of MT include tissue weight [16], reproductive stage [17], temperature [18], and salinity [19]. This limits the use of MT as a tool in biomonitoring, as concentrations may alter independently of metal exposure, particularly in bivalve species.

Literature on the MT response of marine alga to metal exposure is limited, compared to other organisms. MT in spiral wrack (Fucus spiralis) has never been reported. The MT gene has been identified in bladder wrack (Fucus vesiculosus) by Morris et al. [20], which suggested that a protective mechanism against metal exposure exists for this species. Further studies suggest induction in this species following $\mathrm{Cu}$ exposure [5], as well as an ability to bind to $\mathrm{As}, \mathrm{Cd}$, and $\mathrm{Zn}$ [21, 22]. This 
shows potential for MT to be developed as a biomarker in brown seaweeds.

F. spiralis would offer a cosmopolitan bioindicator species for dissolved metal pollution if MT is shown to be a reliable biomarker in this species. It is geographically widely available and easy to sample, suggesting it is a promising candidate. It may also be less susceptible to natural variation compared to traditional MT biomarker species. However, despite the potential for $F$. spiralis to be used as a MT biomarker species, its use has not been developed, and no study of its MT response to metals has been conducted in the field. Therefore, this study aimed to investigate the potential for MT in F. spiralis to be used a biomarker for metal pollution.

\section{Methodology}

\subsection{Sample collection}

Seaweed samples were collected from four sites in Poole Harbour, UK: Holes Bay (north), Holes Bay (south), Poole Quay, and Sandbanks (Figure 1). Samples were carried out in January, April, August, and October, which are referred to as winter, spring, summer, and autumn. Samples were kept in storage at $-20{ }^{\circ} \mathrm{C}$ before analysis, as advised by Oaten et al. [23].

\subsection{MT analysis}

MT concentrations were measured using the UV-spectrophotometric method devised by Viarengo et al. [24], with modifications by Aly et al. [25]. Before analysis, approximately $3 \mathrm{~cm}$ of the frond tips of seaweed were dissected. This was then homogenised using a ceramic blade and a pestle and mortar (to avoid metal contamination before metal analysis). Three replicates of each sample were measured. Concentrations are reported in $\mu \mathrm{g} / \mathrm{g}$ (wet weight).

\subsection{Metal analysis}

Before analysis, previously homogenised samples (as per MT analysis) were freeze-dried for 72 hours. Accurately weighed samples of approximately $10 \mathrm{mg}$ of dried, ground sample were placed in $7 \mathrm{ml}$ Teflon sealable pots. Blank samples consisting of empty Teflon pots were also prepared. Samples were digested in Aqua Regia on a hot plate. Additions of trace metal grade hydrogen peroxide $\left(\mathrm{H}_{2} \mathrm{O}_{2}\right)$ were made to oxidize organic matter. Samples were dried, resuspended, and completed with $3 \%$ trace metal grade, redistilled, nitric acid $\left(\mathrm{HNO}_{3}\right)$, containing $5 \mathrm{ppb} \mathrm{In} / \mathrm{Re}$ and $20 \mathrm{ppb}$ Be as internal standards to correct for matrix effects and instrument drift. Analysis by inductively coupled plasma mass spectrometry (ICPMS) was carried out. A mussel reference material (European Reference Materials - CE278k) was measured as a bivalve comparator and concentrations were adjusted according to the recovery rate. Concentrations are reported as $\mu \mathrm{g} / \mathrm{g}$ (dry weight).

\subsection{Statistical analysis}

All statistical analysis was completed using IBM SPSS Statistic v21. Tests for normality (Shapiro-Wilk) and homogeneity of variance (Levene's test) were completed and data was tested parametrically (one-way ANOVA) or nonparametrically (Kruskall-Wallis test), accordingly. Linear regression was used to determine the effects of metal exposure on MT concentrations in $F$. spiralis. Statistical significance was established at $\mathrm{P}=0.05$.

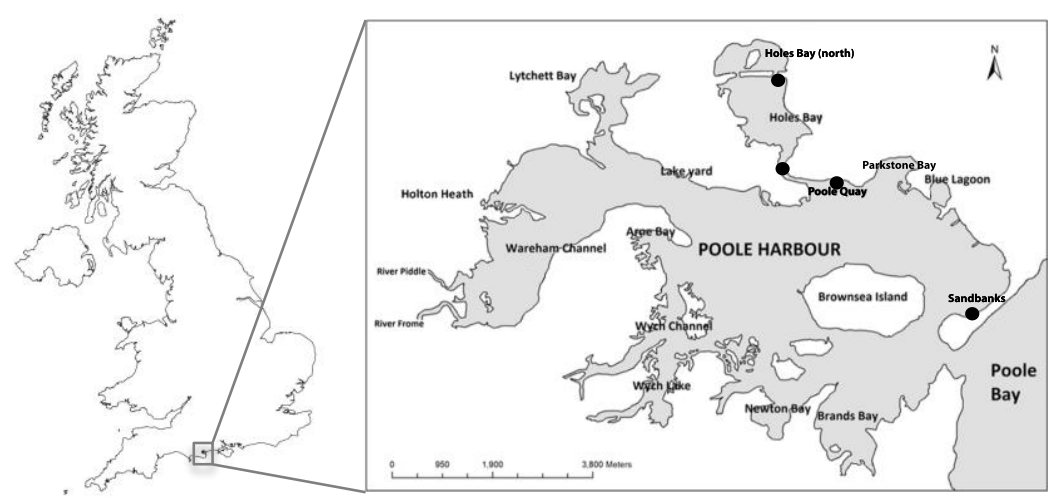

Fig. 1: Site map of Poole Harbour, UK, and sampling locations. 


\section{Results}

MT concentrations in $F$. spiralis varied greatly throughout the sampling year (Figure 2a). In winter, MT concentrations were significantly higher in Holes Bay (north), compared to Holes Bay (south), Poole Quay, and Sandbanks (post-hoc Scheffe, $\mathrm{P}=0.015, \mathrm{P}<0.001, \mathrm{P}<0.001$, respectively). Holes Bay (south) was also significantly higher than Poole Quay and Sandbanks (post-hoc Scheffe, $\mathrm{P}=0.004, \mathrm{P}=0.048$, respectively). Concentrations of MT in F. spiralis from Sandbanks increased in spring, and became highest in summer and autumn. In spring, MT concentrations were higher in Holes Bay (north) compared to Poole Quay (post-hoc Tukey, $\mathrm{P}=0.04$ ). In summer, the concentration of MT in $F$. spiralis from Sandbanks was significantly higher than Poole Quay (post-hoc Scheffe, $\mathrm{P}=0.026$ ). During autumn, significant differences in MT concentrations in $F$. spiralis did not exist between sites $(\mathrm{F}=2.835, \mathrm{P}=0.106)$.

Metal concentrations in $F$. spiralis also varied greatly throughout the sampling year, and were inconsistent in each season (Figure $2 \mathrm{~b}-\mathrm{k}$ ). For Fe, and $\mathrm{Cd}$, highest concentrations were generally found at Holes Bay (north) throughout the year. For Sn and Ni concentrations were highest at Sandbanks in winter and summer, and highest at Holes Bay (north) in spring and autumn. For $\mathrm{Zn}$ highest concentrations were predominantly found at Holes Bay (south), and for Cu during winter and spring. Pb concentrations were highest in F. spiralis at Holes Bay (north), Poole Quay, and Sandbanks in winter, spring, and summer, respectively. Furthermore, concentrations of $\mathrm{Cu}, \mathrm{Zn}$, and $\mathrm{Cd}$ generally decrease from winter to autumn.

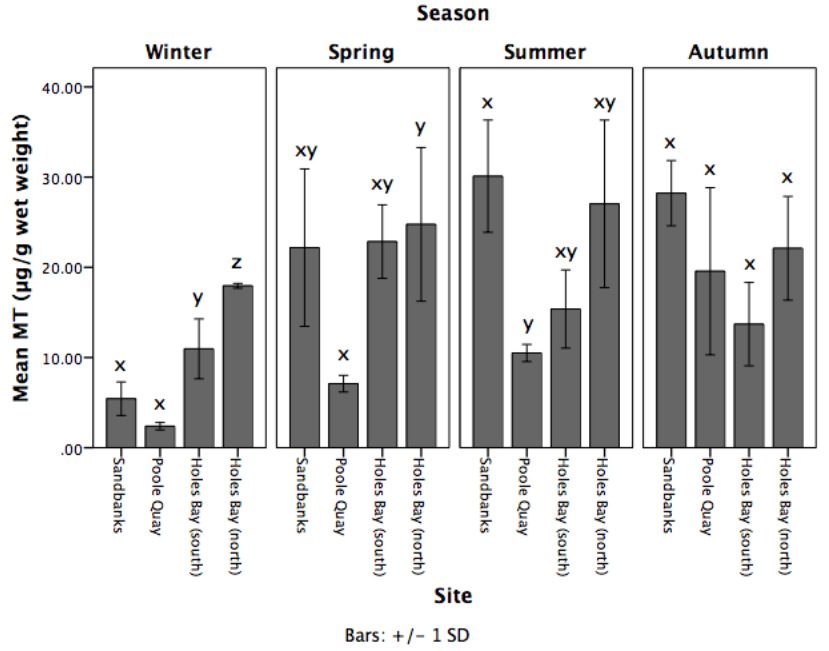

(a)

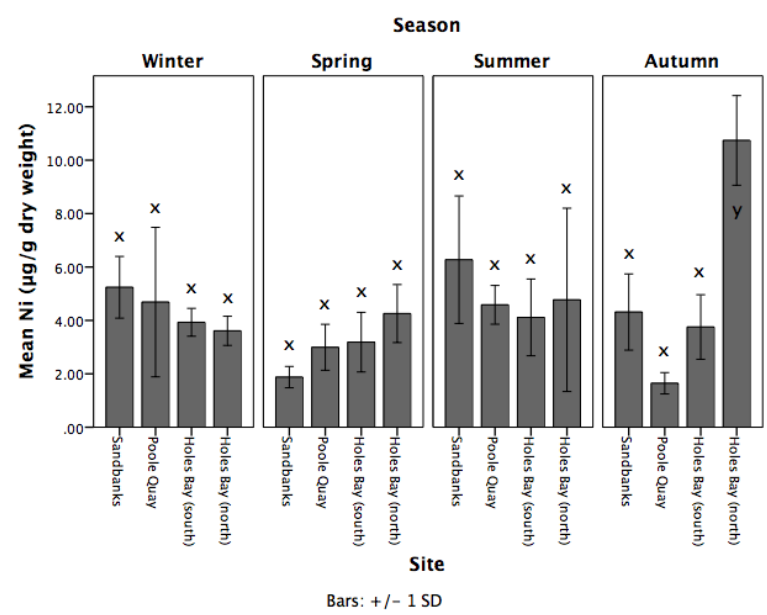

(c)

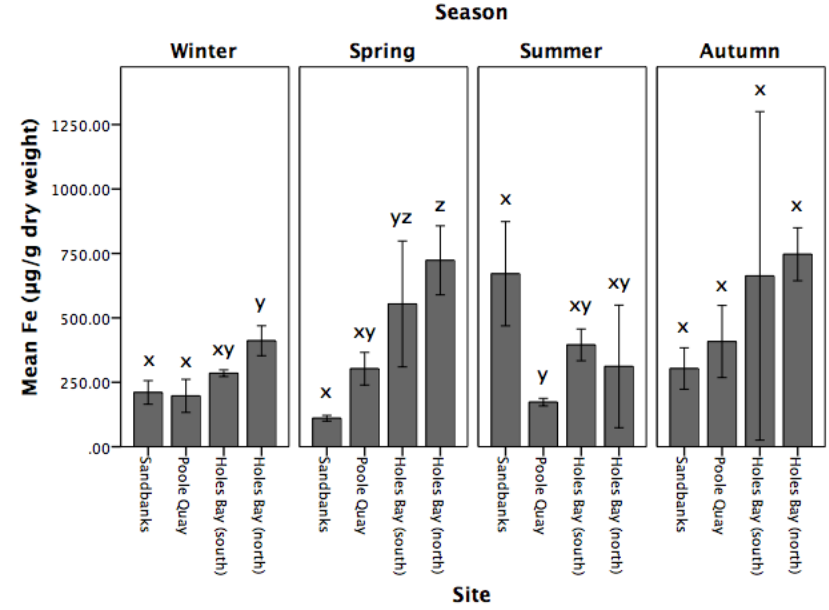

Bars: + /- $1 \mathrm{SD}$

(b)

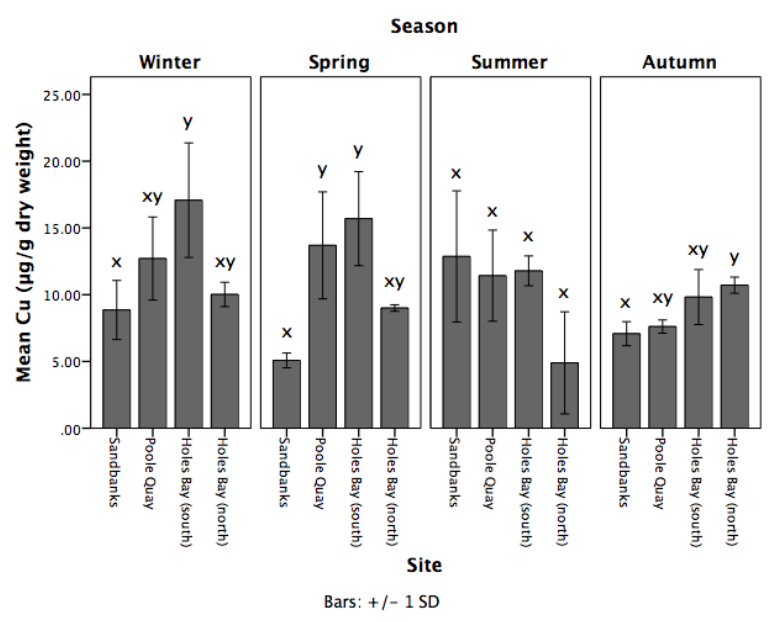

(d)

Fig. 1: Concentrations ( $\mu \mathrm{g} / \mathrm{g}$ ) of a) MT, b) $\mathrm{Fe}$, c) $\mathrm{Ni}$, d) $\mathrm{Cu}, \mathrm{e}) \mathrm{Zn}, \mathrm{f}) \mathrm{Cd}, \mathrm{g}) \mathrm{Sn}, \mathrm{h}) \mathrm{Pb}$ in $F$. spiralis from Poole Harbour throughout each season in 2015, with standard deviation (SD) $(n=3)$. Different letters $(x, y, z)$ indicate significant differences between sites $(P$ $=0.05)$. 


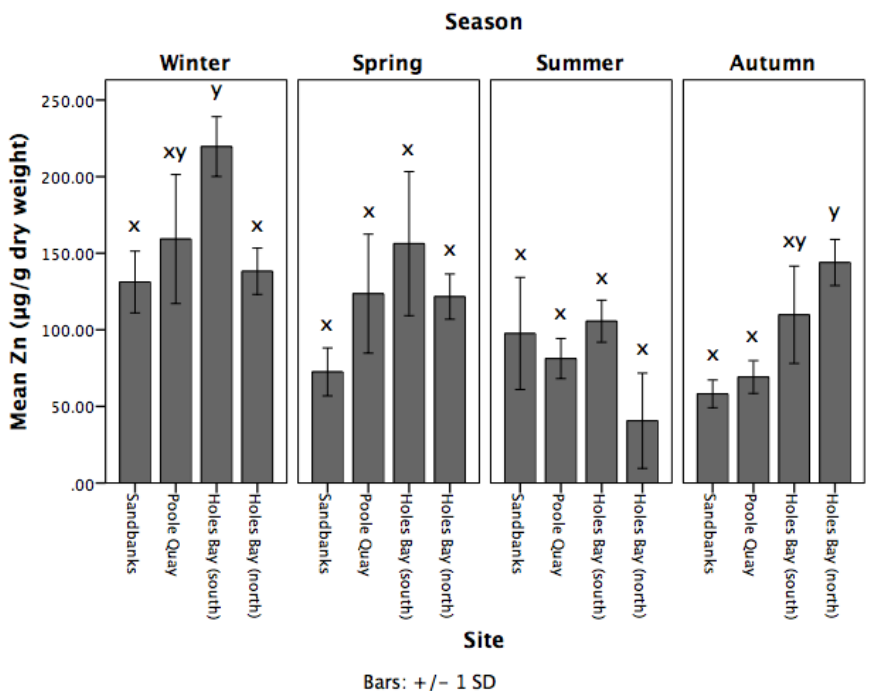

(e)

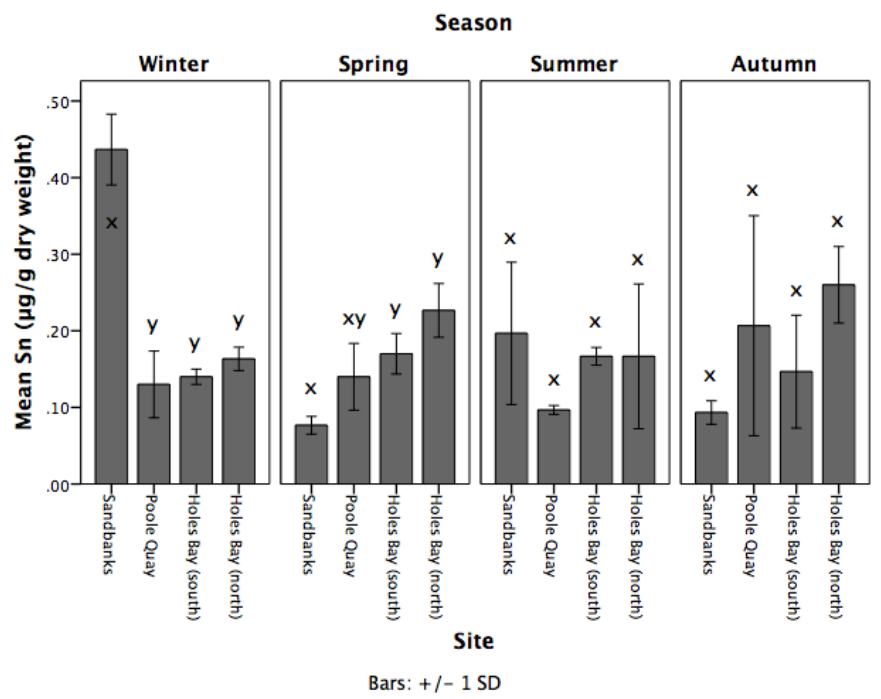

$(\mathrm{g})$

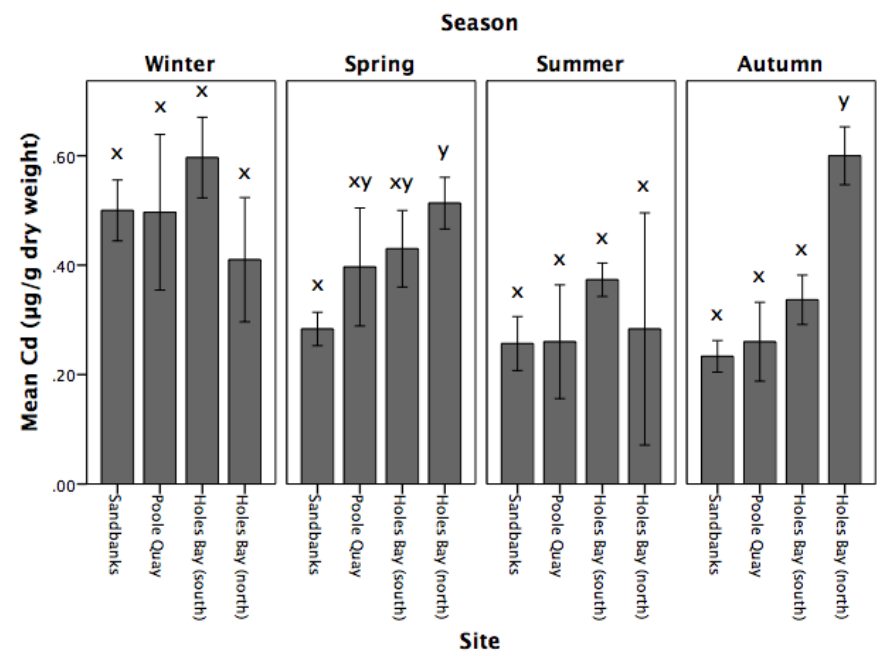

Bars: +/- $1 \mathrm{SD}$

(f)

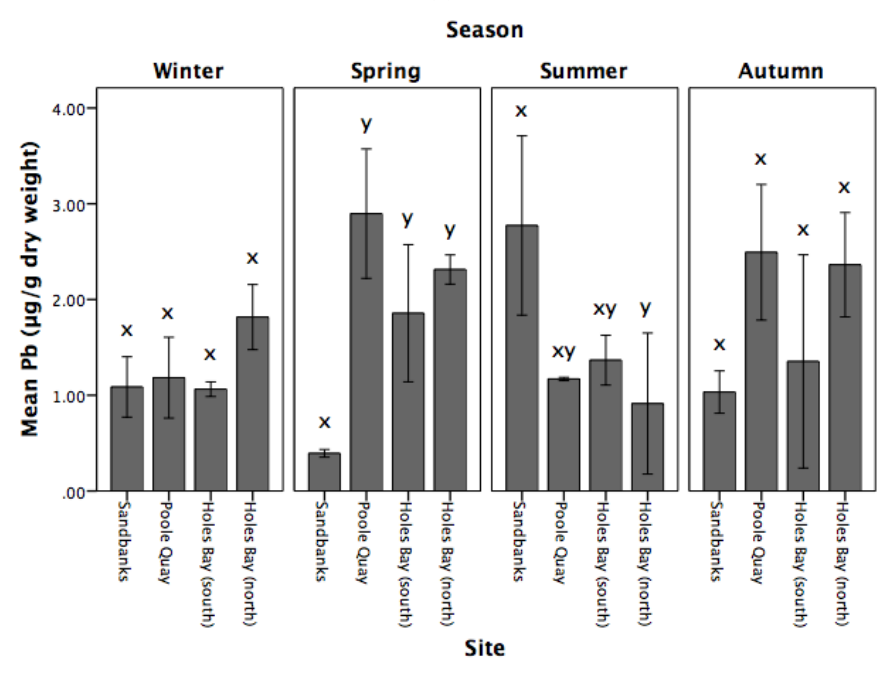

Bars: + /- 1 SD

(h)

Fig. 2 cont: Concentrations ( $\mu$ g/g) of a) MT, b) Fe, c) Ni, d) Cu, e) Zn, f) Cd, g) Sn, h) Pb in F. spiralis from Poole Harbour throughout each season in 2015, with standard deviation (SD) $(n=3)$. Different letters $(x, y, z)$ indicate significant differences between sites $(\mathrm{P}=0.05)$.

Linear regression analysis was used to assess the effect of metal exposure on MT concentration (Figure 3). During winter, only Fe tissue concentration showed a significant positive relationship with $M T$ concentration $\left(R^{2}=0.792, P<0.001\right)$. No significant positive relationships existed during spring or autumn. In summer, significant positive relationships were evident, and existed between MT concentrations and $\mathrm{Fe}\left(\mathrm{R}^{2}=0.631, \mathrm{P}=0.002\right), \mathrm{Ni}\left(\mathrm{R}^{2}=0.486, \mathrm{P}=0.012\right), \mathrm{Sn}\left(\mathrm{R}^{2}=0.579\right.$, $\mathrm{P}=0.004)$, and $\mathrm{Pb}\left(\mathrm{R}^{2}=0.415, \mathrm{P}=0.024\right)$.

\section{Discussion}

\subsection{Metal contamination and seasonal variation}

Concentrations of metals in F. spiralis from Poole Harbour indicate that the most polluted area is Holes Bay. This is in agreement with previous literature on metal contamination in Poole Harbour [26, 27]. F. spiralis metal concentrations at Sandbanks were also relatively high. This may be due to the sewage pumping station near to the site, which periodically discharges storm water. There are also yacht clubs in the vicinity, which may contribute to the metal burden in the area due 
to sources of metals such as anti-fouling paints on watercraft: higher Sn concentrations in winter could be related to boat maintenance in winter and the removal of old tributyl tin antifoulant.

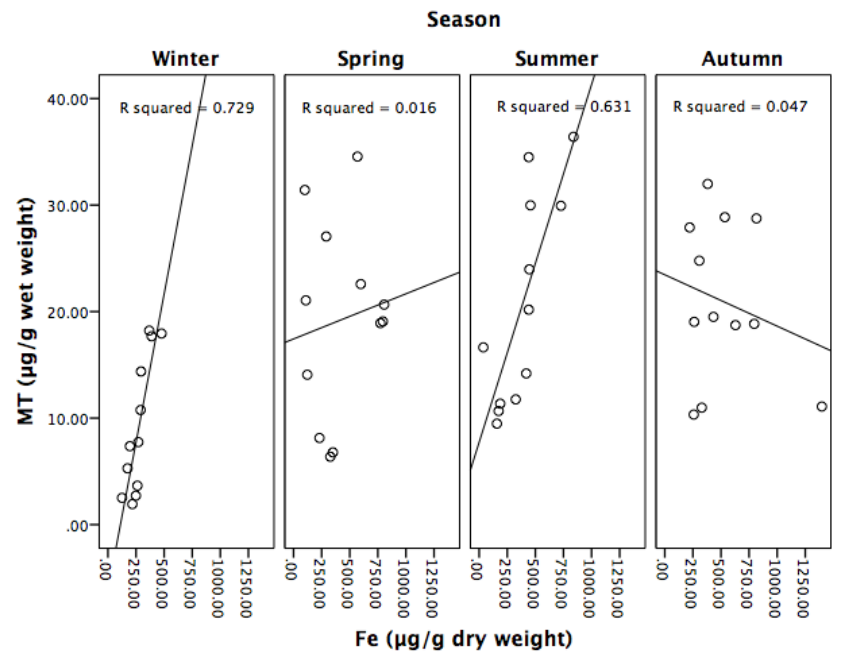

(a)

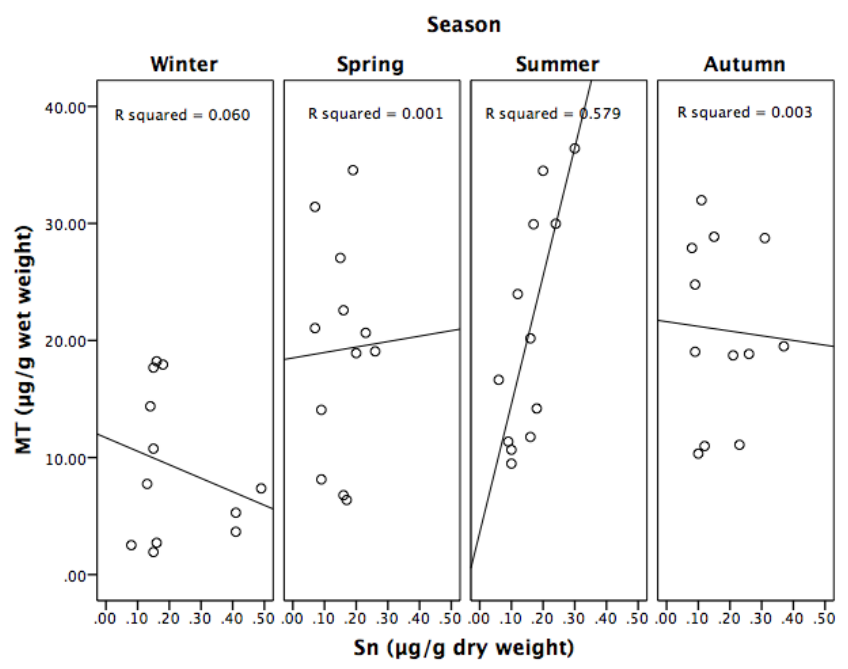

(c)

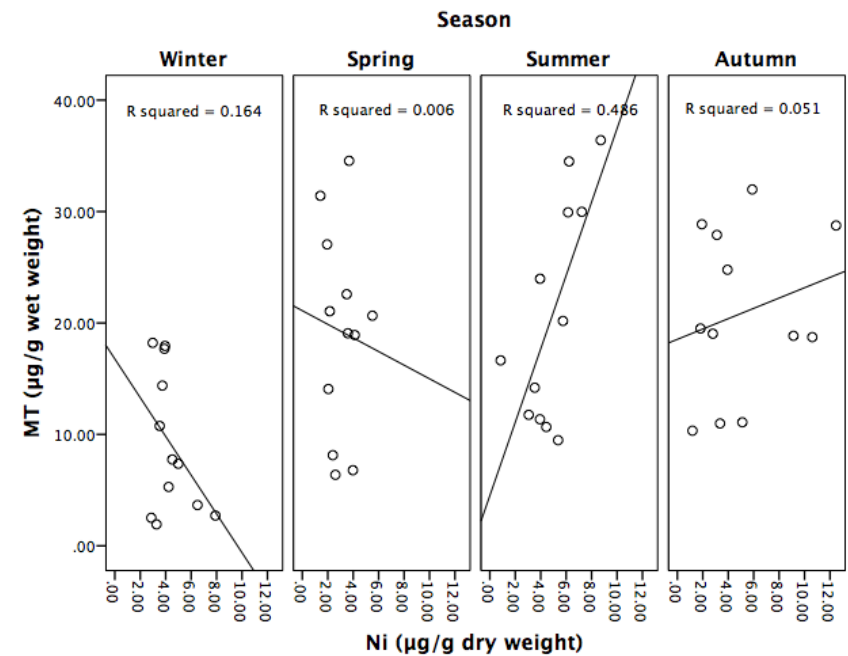

(b)

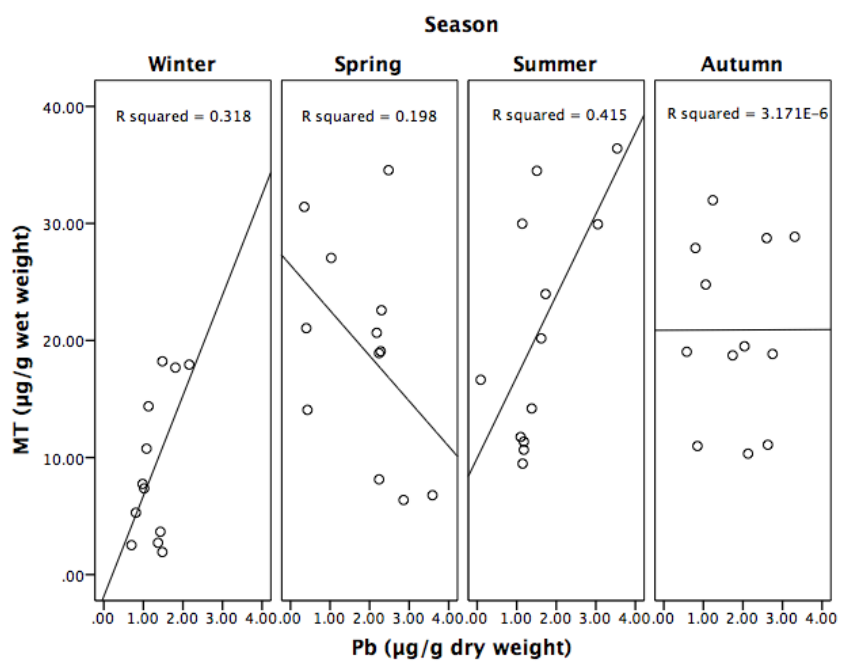

(d)

Fig. 2: Linear regression between concentrations of MT and a) Fe, b) Ni, c) Sn, d) $\mathrm{Pb}$ in $F$. spiralis from Poole Harbour across seasons in 2015 .

Seasonal variation for some metal concentrations in F. spiralis is apparent, and metal concentrations tend to reduce from winter to autumn. This could be explained by plant growth. Concentrations could continue to mount through dormant periods during winter, and dilute as plants grow and reproduce in summer months $[28,29]$. Other factors may also influence seasonal variability between metals such as reduced bioavailability of certain dissolved metals to seaweeds, such as cadmium, due to uptake by phytoplankton in summer months [30]. Seasonal variation may be particularly relevant for $\mathrm{Cd}$ and $\mathrm{Zn}$, but less difference is observed for $\mathrm{Pb}[31,32]$. This is in agreement with this study. An ion-exchange process may be involved in $\mathrm{Pb}$ uptake, and could explain fewer differences in concentrations between seasons [33].

\subsection{Metal toxicity and MT induction}

The induction of MT is a physiological response to the insult caused by metal exposure [20, 21]. Therefore, toxic metals are more likely to cause MT induction. The order of toxicity of metals to seaweed species is generally $\mathrm{Hg}>\mathrm{Cu}>\mathrm{Cd}$ $>\mathrm{Ag}>\mathrm{Pb}>\mathrm{Zn}$ [34]. $\mathrm{Cu}$, despite being an essential metal, is the second most toxic metal to seaweeds, the effects of which 
have been extensively studied due to its use in antifouling paints $[34,35]$. It is often cited to inhibit photosynthetic processes and retard growth in seaweed species [36-38]. In addition, inhibition of fertilization and reproduction resulting from Cu exposure has been identified in $F$. spiralis [39]. Pb has also been shown to impact photosynthetic efficiency and growth, but is less toxic than $\mathrm{Cu}[36,40]$. Cd can affect growth, pigment content, and carbon assimilation [41]. $\mathrm{Zn}$ has also been shown to slow growth in seaweeds [42].

There is limited knowledge on MT response to metal exposure in seaweeds, though few studies exist on F. vesiculosus. Morris et al. [20] noted the MT gene in F. vesiculosus to be induced by $\mathrm{Cu}$ exposure, and MT can bind to both $\mathrm{Cu}$ and $\mathrm{Cd}$. Further studies confirmed its role as a detoxification mechanism for metals, and reported MT binding abilities to Zn, and As $[21,22]$. However, only Owen et al. [5] confirmed this role in the field in vivo. The study found MT to respond to $\mathrm{Cu}$ exposure, and this metal was found to be more important for MT induction, due to a stronger and more significant regression coefficient, compared to $\mathrm{Zn}$ and $\mathrm{Fe}$. In this study, $\mathrm{Cu}, \mathrm{Zn}$, and As seemed not elicit a MT response in $F$. spiralis. Fe, Ni, Sn and $\mathrm{Pb}$ showed a significant positive relationship with MT in $F$. spiralis, during summer. Previous studies have not reported MT induction in Fucus spp. following exposure from these metals, with the exception of Fe [5]. However, these metals are known to induce MT in other species [43, 44]. Otherwise, it is possible these metals are contributing to a combination effect with other more toxic metals, such as $\mathrm{Cu}$, and are cumulatively above a threshold for MT induction [45]. Another possibility is that these metals are correlated with more toxic metals, not recorded here, that are eliciting a MT response in F. spiralis.

\subsection{Influences of MT response and variability}

MT concentrations in $F$. spiralis were generally low for most of the year and were not related to tissue metal concentrations. This may be due to relatively low levels of metal exposure in Poole Harbour. Seaweed species are very tolerant of metal exposure [3]. As such, the concentrations in Poole Harbour may not be enough to elicit a MT response. A study by Owen et al. [5] reported $F$. vesiculosus to begin exhibiting the gene for MT when exposed to a concentration of Cu of $30 \mu \mathrm{g} / \mathrm{l}$. However, Cu concentrations in seawater in Poole Harbour do not exceed $3 \mu \mathrm{g} / 1$ [26]. For comparison, Zn, Fe, and $\mathrm{Pb}$ concentrations in $F$. vesiculosus from the Fal Estuary, Cornwall, were as much as an order of magnitude higher, with $\mathrm{Cu}$ two orders of magnitudes higher, compared to this study [46]. Owen et al. [5] did not report tissue concentrations as high in $F$. vesiculosus from the Fal Estuary; perhaps indicating a recovery of contamination levels, but the most polluted site studied was still approximately ten, five, and ten times higher respectively for $\mathrm{Cu}, \mathrm{Zn}$ and $\mathrm{Fe}$ concentrations than in F. spiralis in this study.

Aside from low seawater concentrations, low accumulation of metals in seaweeds from Poole Harbour may be the product of low metal concentrations in the tips of fronds, with greater concentrations in the thallus [46]. It has been suggested to dissect the frond at a pre-determined distance from the distal end $(10 \mathrm{~cm}$ for $F$. vesiculosus $)$ to allow time for new growth to equilibrate with the environment $[47,48]$. In this study, tips of seaweeds were analysed in order to select the tissue that reflected the most recent metal concentrations in the surrounding water [37]. However, it may be more suitable to analyse metal exposure and MT response in mature tissue in the thallus, due to potentially higher metal, and likely MT, concentrations. This may also explain the large degree of variation in metal and MT concentrations, evidenced by large standard deviations.

Biological processes may provide insight as to why metals only seem to elicit a MT response in this species during summer. It is known that prolonged exposure to metals can cause damage to growth rates and photosynthetic efficiency in seaweeds [36]. This is likely due to the redirection of energy for defensive pathways, as well as the oxidation of photosynthetic pigments [49, 50]. It may also be related to the substitution of $\mathrm{Mg}$ within chlorophyll inhibiting photosystem II leading to chloroplast dysfunction [38]. The seasonality of these processes, with maximums in summer, could suggest that metal toxicity to seaweeds is greater during these periods. Therefore, detoxification processes, such as the induction of MT, may increase in summer.

\section{Conclusion}

The use of MT in F. spiralis as a sensitive biomarker of metal pollution at low concentrations, as subjected in Poole Harbour, is shown here to be limited, as MT does not appear to be consistently induced. However, during summer, concentrations of MT increase, and linear regression analysis reveals significant positive relationships with certain metals. This may be due to increased toxicity of metals as they inhibit photosynthetic processes and growth, which becomes pertinent in summer months. Consequently, MT in F. spiralis may be able to relay the biological impact of metals at low environmental concentrations during periods when important physiological processes are taking place, such as seasonal growth. This 
research demonstrates the potential for using MT in F. spiralis as a biomarker for metal pollution, for the first time. Further research is needed to fully evaluate its potential in brown seaweeds, and develop them as cosmopolitan bioindicator species. Care should be taken to address uncertainties in frond selection and seasonal effects.

\section{Acknowledgements}

The authors would like to thank the Engineering and Physical Sciences Research Council (EP/L505067/1) and the Southampton Marine and Maritime Institute (SMMI) for jointly financing this study. Thanks are also due to Professor John Humphreys, for assistance with field sampling, and Dr Matthew Cooper for laboratory assistance and advice.

\section{References}

[1] P. S. Rainbow, "Biomonitoring of heavy metal availability in the marine environment," Marine Pollution Bulletin, vol. 31, pp. 183-192, 1995.

[2] H. D. Nielsen and S. L. Nielsen, "Photosynthetic responses to $\mathrm{Cu}^{2+}$ exposure are independent of light acclimation and uncoupled from growth inhibition in Fucus serratus (Phaeophyceae)," Marine Pollution Bulletin, vol. 51, pp. 715-721, 2005.

[3] B. Pawlik-Skowronska, J. Pirszel, and M. T. Brown, "Concentrations of phytochelatins and glutathione found in natural assemblages of seaweeds depend on species and metal concentrations of the habitat," Aquatic Toxicology, vol. 83, pp. 190-199, 2007.

[4] J. A. Vasquez and N. Guerra, "The use of seaweeds as bioindicators of natural and anthropogenic contaminants in northern Chile," Hydrobiologia, vol. 327, pp. 327-333, 1996.

[5] J. R. Owen, C. A. Morris, B. Nicolaus, J. L. Harwood, and P. Kille, "Induction of expression of a 14-3-3 gene in response to copper exposure in the marine alga, Fucus vesiculosus," Ecotoxicology, vol. 21, pp. 124-138, 2012.

[6] J. H. R. Kagi and Y. Kojima, "Chemistry and biochemistry of metallothionein," Biochemistry, vol. 27, pp. 8509-8515, 1987.

[7] J. C. Amiard, C. Amiard-Triquet, S. Barka, J. Pellerin, and P. S. Rainbow, "Metallothioneins in aquatic invertebrates: Their role in metal detoxification and their use as biomarkers," Aquatic Toxicology, vol. 76, pp. 160-202, 2006.

[8] C. D. Klaassen, J. Liu, and S. Choudhuri, "Metallothionein: An intracellular protein to protect against cadmium toxicity," Annual Review of Pharmacology and Toxicology, vol. 39, pp. 267-294, 1999.

[9] M. J. Bebianno and W. J. Langston, "Metallothionein induction in Mytilus edulis exposed to cadmium," Marine Biology, vol. 108, pp. 91-96, 1991.

[10] N. Geng, C. Wang, P. F. Wang, N. Qi, and L. X. Ren, "Cadmium accumulation and metallothionein response in the freshwater bivalve Corbicula fluminea under hydrodynamic conditions," Biological Trace Element Research, vol. 165, pp. 222-232, 2015.

[11] S. N. Frank, C. Singer, and B. Sures, "Metallothionein (MT) response after chronic palladium exposure in the zebra mussel, Dreissena polymorpha," Environmental Research, vol. 108, pp. 309-314, 2008.

[12] A. Serafim and M. J. Bebianno, "Kinetic model of cadmium accumulation and elimination and metallothionein response in Ruditapes decussatus," Environmental Toxicology and Chemistry, vol. 26, pp. 960-969, 2007.

[13] A. Geffard, J. C. Amiard, and C. Amiard-Triquet, "Use of metallothionein in gills from oysters (Crassostrea gigas) as a biomarker: seasonal and intersite fluctuations," Biomarkers, vol. 7, pp. 123-137, 2002.

[14] A. Viarengo, B. Burlando, N. Ceratto, and I. Panfoli, "Antioxidant role of metallothioneins: A comparative overview," Cellular and Molecular Biology, vol. 46, pp. 407-417, 2000.

[15] T. T. Le, S. Zimmermann, and B. Sures, "How does the metallothionein induction in bivalves meet the criteria for biomarkers of metal exposure?," Environ Pollut, vol. 212, pp. 257-68, 2016.

[16] B. Raspor, Z. Dragun, M. Erk, D. Ivankovic, and J. Pavicic, "Is the digestive gland of Mytilus galloprovincialis a tissue of choice for estimating cadmium exposure by means of metallothioneins?," Science of the Total Environment, vol. 333, pp. 99-108, 2004.

[17] V. Moschino, E. Delaney, and L. Da Ros, "Assessing the significance of Ruditapes philippinarum as a sentinel for sediment pollution: Bioaccumulation and biomarker responses," Environmental Pollution, vol. 171, pp. 52-60, 2012.

[18] W. Smaoui-Damak, B. Berthet, and A. Hamza-Chaffai, "In situ potential use of metallothionein as a biomarker of cadmium contamination in Ruditapes decussatus," Ecotoxicology and Environmental Safety, vol. 72, pp. 1489-1498, 2009. 
[19] S. Legras, C. Mouneyrac, J. C. Amiard, C. Amiard-Triquet, and P. S. Rainbow, "Changes in metallothionein concentrations in response to variation in natural factors (salinity, sex, weight) and metal contamination in crabs from a metal-rich estuary," Journal of Experimental Marine Biology and Ecology, vol. 246, pp. 259-279, 2000.

[20] C. A. Morris, B. Nicolaus, V. Sampson, J. L. Harwood, and P. Kille, "Identification and characterization of a recombinant metallothionein protein from a marine alga, Fucus vesiculosus," Biochemical Journal, vol. 338, pp. 553$560,1999$.

[21] M. E. Merrifield, J. Chaseley, P. Kille, and M. J. Stillman, "Determination of the Cd/S cluster stoichiometry in Fucus vesiculosus metallothionein," Chemical Research in Toxicology, vol. 19, pp. 365-375, 2006.

[22] T. T. Ngu, J. A. Lee, M. K. Rushton, and M. J. Stillman, "Arsenic metalation of seaweed Fucus vesiculosus metallothionein: The importance of the interdomain linker in metallothionein," Biochemistry, vol. 48, pp. 8806-8816, 2009.

[23] J. F. Oaten, M. D. Hudson, A. C. Jensen, and I. D. Williams, "Effects of organism preparation in metallothionein and metal analysis in marine invertebrates for biomonitoring marine pollution," Science of the Total Environ, vol. 518-519, pp. 238-47, 2015.

[24] A. Viarengo, E. Ponzano, F. Dondero, and R. Fabbri, "A simple spectrophotometric method for metallothionein evaluation in marine organisms: An application to Mediterranean and Antarctic molluscs," Marine Environmental Research, vol. 44, pp. 69-84, 1997.

[25] W. Aly, I. D. Williams, and M. D. Hudson, "Limitations of metallothioneins in common cockles (Cerastoderma edule) and sponges (Haliclona oculata) as biomarkers of metal contamination in a semi-enclosed coastal area," Science of the Total Environment, vol. 473, pp. 391-397, 2014.

[26] W. Aly, I. D. Williams, and M. D. Hudson, "Metal contamination in water, sediment and biota from a semi-enclosed coastal area," Environmental Monitoring and Assessment, vol. 185, pp. 3879-3895, 2013.

[27] W. J. Langston, B. S. Chesman, G. R. Burt, S. J. Hawkins, J. Readman, and P. Worsfold, "Site characterization of the South West European Marine sites - Poole Harbour SPA," 2003.

[28] R. Fuge and K. H. James, "Trace metal concentrations in Fucus from the Bristol Channel," Marine Pollution Bulletin, vol. 5, pp. 9-12, 1974.

[29] R. Villares, P. X, and A. Carballeira, "Seasonal variation and background levels of heavy metals in two green seaweeds," Environmental Pollution, vol. 119, pp. 79-90, 2002.

[30] C. Pohl, G. Kattner, and M. Schulzbaldes, "Cadmium, copper, lead and zinc on transects through Arctic and eastern Atlantic surface and deep waters," Journal of Marine Systems, vol. 4, pp. 17-29, 1993.

[31] F. Riget, P. Johansen, and G. Asmund, "Natural seasonal-variation of cadmium, copper, lead and zinc in brown seaweed (Fucus vesiculosus)," Marine Pollution Bulletin, vol. 30, pp. 409-413, 1995.

[32] P. Miramand and D. Bentley, "Heavy-metal concentrations in 2 biological indicators (Patella vulgata and Fucus serratus) collected near the french nuclear-fuel reprocessing plant of la-hague," Science of the Total Environment, vol. 111, pp. 135-149, 1992.

[33] I. Eide, S. Myklestad, and S. Melsom, "Long-term uptake and release of heavy-metals by Ascophyllum nodosum (L) Le Jol (Phaeophyceae) insitu," Environmental Pollution Series a-Ecological and Biological, vol. 23, pp. 19-28, 1980.

[34] S. Lobban and P. J. Harrison, Seaweed Ecology and Physiology. Cambridge: Cambridge University Press, 1994.

[35] S. M. Coelho, J. W. Rijstenbil, and M. T. Brown, "Impacts of anthropogenic stresses on the early development stages of seaweeds," Journal of Aquatic Ecosystem Stress and Recovery, vol. 7, pp. 317-333, 2000.

[36] G. B. Costa, M. R. L. de Felix, C. Simioni, F. Ramlov, E. R. Oliveira, D. T. Pereira, et al., "Effects of copper and lead exposure on the ecophysiology of the brown seaweed Sargassum cymosum," Protoplasma, vol. 253, pp. 111-125, 2016.

[37] S. Connan and D. B. Stengel, "Impacts of ambient salinity and copper on brown algae: 1. Interactive effects on photosynthesis, growth, and copper accumulation," Aquatic Toxicology, vol. 104, pp. 94-107, 2011.

[38] H. Kupper, I. Setlik, M. Spiller, F. C. Kupper, and O. Prasil, "Heavy metal-induced inhibition of photosynthesis: Targets of in vivo heavy metal chlorophyll formation," Journal of Phycology, vol. 38, pp. 429-441, 2002.

[39] P. R. Bond, M. T. Brown, R. M. Moate, M. Gledhill, S. J. Hill, and M. Nimmo, "Arrested development in Fucus spiralis (Phaeophyceae) germlings exposed to copper," European Journal of Phycology, vol. 34, pp. 513-521, 1999.

[40] J. G. Stewart, "Effects of lead on the growth of four species of red algae," Phycologia, vol. 16, pp. 31-36, 1977.

[41] J. W. Markham, B. P. Kremer, and K. R. Sperling, "Effects of cadmium on Laminaria saccharina in culture," Marine Ecology Progress Series, vol. 3, pp. 31-39, 1980. 
[42] I. M. Munda and V. Hudnik, "The effects of zn, mn, and co accumulation on growth and chemical-composition of Fucus vesiculosus L under different temperature and salinity conditions," Marine Ecology-Pubblicazioni Della Stazione Zoologica Di Napoli I, vol. 9, pp. 213-225, 1988.

[43] J. C. Amiard, R. Journel, and H. Bacheley, "Influence of field and experimental exposure of mussels (Mytilus sp.) to nickel and vanadium on metallothionein concentration," Comparative Biochemistry and Physiology C-Toxicology \& Pharmacology, vol. 147, pp. 378-385, 2008.

[44] I. V. Seregin and V. B. Ivanov, "Physiological aspects of cadmium and lead toxic effects on higher plants," Russian Journal of Plant Physiology, vol. 48, pp. 523-544, 2001.

[45] A. Serafim and M. J. Bebianno, "Effect of a polymetallic mixture on metal accumulation and metallothionein response in the clam Ruditapes decussatus," Aquatic Toxicology, vol. 99, pp. 370-378, 2010.

[46] G. W. Bryan and L. G. Hummerstone, "Brown seaweed as an indicator of heavy-metals in estuaries in southwest England," Journal of the Marine Biological Association of the United Kingdom, vol. 53, pp. 705-720, 1973.

[47] P. S. Rainbow, B. D. Smith, and S. S. S. Lau, "Biomonitoring of trace metal availabilities in the Thames estuary using a suite of littoral biomonitors," Journal of the Marine Biological Association of the United Kingdom, vol. 82, pp. 793$799,2002$.

[48] G. W. Bryan, W. J. Langston, L. G. Hummerstone, and G. R. Burt, "A guide to the assessment of heavy-metal contamination in estuaries," Occasional Publications. Marine Biological Association of the United Kingdom, vol. 4, pp. $1-92,1985$.

[49] J. Collen, E. Pinto, M. Pedersen, and P. Colepicolo, "Induction of oxidative stress in the red macroalga Gracilaria tenuistipitata by pollutant metals," Archives of Environmental Contamination and Toxicology, vol. 45, pp. 337-342, 2003.

[50] E. Pinto, T. C. S. Sigaud-Kutner, M. A. S. Leitao, O. K. Okamoto, D. Morse, and P. Colepicolo, "Heavy metal-induced oxidative stress in algae," Journal of Phycology, vol. 39, pp. 1008-1018, 2003. 